\title{
Preface to 'Late Triassic Terrestrial Biotas and the Rise of Dinosaurs' Special Issue
}

\author{
Richard J. Butler ${ }^{1}$, Randall B. Irmis ${ }^{2}$ and Max C. Langer ${ }^{3}$
}

\author{
${ }^{1}$ Bayerische Staatssammlung für Paläontologie und Geologie, Richard-Wagner-Straße 10, 80333 Munich, Germany \\ Email: r.butler@1rz.uni-muenchen.de \\ ${ }^{2}$ Utah Museum of Natural History and Department of Geology \& Geophysics, University of Utah, 1390 E. Presidents \\ Circle, Salt Lake City, UT 84112-0050, USA \\ Email: irmis@umnh.utah.edu \\ ${ }^{3}$ Departamento de Biologia, FFCLRP-USP, Av. Bandeirantes 3900, Ribeirão Preto, Brazil \\ Email: mclanger@ffclrp.usp.br
}

The early Mesozoic records an important transition in the history of the Earth's terrestrial ecosystems. As they recovered from the largest known mass extinction (the end-Permian event), organisms in these ecosystems transitioned to new forms that eventually evolved into the classic Mesozoic biotas, and laid the foundations for many groups still flourishing today (Fraser 2006; Irmis \& Whiteside 2010; Sues \& Fraser 2010). All of this was set against a backdrop of dynamic climatic and physical events that shaped these biotas. This early Mesozoic terrestrial transition reached its culmination in many ways during the Late Triassic, when ecosystems had largely recovered from the end-Permian extinction, but had not yet been affected by the end-Triassic mass extinction (Fraser \& Sues this volume). Thus, we see a combination of taxa, with some groups that would not survive the end of the Triassic living alongside early representatives of lineages that flourished later in the Mesozoic (e.g., Fraser 2006; Irmis et al. 2007; Brusatte et al. 2008; Sues \& Fraser 2010, this volume) and in some cases are still diverse today. Just one example of this transition, recorded during the Late Triassic, is the origin and diversification of non-avian dinosaurs, the iconic representatives of Mesozoic terrestrial ecosystems (Brusatte et al. 2010; Langer et al. 2010). Although small and rare components of their respective biotas when they first evolved $\sim 231 \mathrm{Ma}$, dinosaurs were abundant and had a near-worldwide distribution by the beginning of the Jurassic Period ( $201 \cdot 3 \mathrm{Ma})$.

Given the importance of the Late Triassic terrestrial transition, it is no surprise that there has been a renaissance in the study of Late Triassic terrestrial biotas, particularly with respect to fossil vertebrates (see recent reviews in Brusatte et al. 2010; Sues \& Fraser 2010, this volume; Irmis \& Whiteside 2010; Langer et al. 2010). New fossil discoveries, re-evaluation of existing specimens, and new quantitative meta-analyses of synthetic datasets have significantly changed our view of this transition in the last 15 years. Nonetheless, the last multiauthored volumes to review this transition are over 25 and 15 years old (Padian 1986; Fraser \& Sues 1994); no new similar synthetic multi-authored view is available. We hope this volume goes some way towards redressing this situation.

The renewed interest and breadth of research into Late Triassic terrestrial vertebrate palaeontology and need for a new synthesis led the Editors (RJB, RBI and MCL) to convene a special symposium on 'Late Triassic Terrestrial Biotas and the Rise of Dinosaurs' for the 2009 Society of Vertebrate Paleontology Annual Meeting in Bristol, United Kingdom. This symposium brought together over 16 presentations covering numerous aspects of the Late Triassic transition. Many of these new research results are presented for the first time as papers in the present volume. Here, we give a brief description of the 'state of the art' in Late Triassic terrestrial vertebrate palaeontology, focusing in part, but not exclusively, on dinosaur origins.

Any evolutionary study in deep time requires a robust geochronologic framework to calibrate the age of fossil taxa and their palaeoenvironmental context. These data are critical for understanding the tempo of change and diversification in particular clades (e.g., early dinosaurs). They are also necessary for comparisons between different fossil assemblages and geological units, because accurate data on stratigraphic ordering of fossil assemblages is essential to determine whether potential differences can be ascribed to variation across space versus time. The study of Late Triassic terrestrial biotas is certainly no exception. Unfortunately, the Late Triassic is particularly devoid of published high-resolution radioisotopic ages (Mundil et al. 2010), and these are particularly few for non-marine strata, making correlation between assemblages and to the marine timescale very difficult (Irmis et al. 2010; Fraser \& Sues this volume). Thus, palynofloral and vertebrate biostratigraphy have been the dominant methods of correlation for non-marine Late Triassic strata (e.g., Litwin et al. 1991; Cornet 1993; Lucas 1998, 2010), but this does not afford the precision necessary for detailed comparisons, and its accuracy has certainly been controversial (e.g., Langer 2005; Rayfield et al. 2005, 2009; Schultz 2005; Irmis et al. 2010).

One bright spot in Late Triassic terrestrial geochronology is the Newark Supergroup of eastern North America, where a $\sim 35$ million year record of lacustrine sedimentation from multiple rift basins provides a precise and accurate highresolution timescale (Kent \& Olsen 1999; Muttoni et al. 2004; Olsen et al. this volume). The Newark Supergroup Astronomically-Calibrated Geomagnetic Polarity Time Scale (Newark APTS) is derived predominantly from the Newark Basin, and consists of high-resolution magnetostratigraphy calibrated by radioisotopic dates and orbitally-paced cyclostratigraphy, allowing for precision of $\sim 20 \mathrm{ka}$ or less (Olsen et al. this volume). The high-resolution magnetostratigraphy allows correlation to classic Tethyan marine sections (and thus the marine timescale) (Muttoni et al. 2004), and the co-occurrence of extensive palynomorph assemblages allows correlation to existing palynomorph biostratigraphic schemes (Olsen et al. this volume). In concert with emerging radioisotopic data from sections containing terrestrial vertebrates 
(e.g., Irmis \& Mundil 2008, 2010; Ramezani et al. 2009), the Newark APTS allows confident correlations between important terrestrial fossil assemblages (Olsen et al. this volume).

These absolute age data can also help recast previous vertebrate biostratigraphic schemes as examinations of faunal change rather than strictly a correlation tool. However, for either use, one must have a precise and accurate lithostratigraphic framework, with detailed plots of individual fossil occurrences. Such detailed records have been rare in the past (cf. Rogers et al. 1993), but researchers are now beginning to produce such records. For example, a revised lithostratigraphy, along with precise stratigraphic placement of fossil discoveries, has revolutionised our understanding of vertebrate faunal change in the classic Upper Triassic Chinle Formation sections at Petrified Forest National Park, Arizona, USA (Parker \& Martz this volume). These data demonstrate a sudden mid-Norian turnover that may correlate with major palaeoenvironmental perturbations (Parker \& Martz this volume).

The palaeoenvironmental context of the Late Triassic terrestrial transition has become increasingly important as workers address the processes that affected these ecosystems. Recent studies have identified abrupt palaeoenvironmental changes reflected in the carbon cycle and depositional environment that correlate with major vertebrate faunal changes (e.g., Whiteside et al. 2010; Olsen et al. this volume; Parker \& Martz this volume). Similarly, major differences in coeval assemblages from across the globe may reflect latitudinal or other climatic differences (Fraser 2006; Irmis et al. 2007; Nesbitt et al. 2009; Ezcurra 2010a; Ezcurra et al. this volume; Fraser \& Sues this volume; Irmis this volume; Olsen et al. this volume). These differences could also explain unusual faunal occurrences, such as the late-surviving giant dicynodonts in northeastern Europe (Dzik et al. 2008; Sulej et al. this volume). Further investigation of Late Triassic palaeoenvironments with new analytical methods should prove to be a powerful test of these climatic-biotic hypotheses (e.g., Dunlavey et al. 2009; Marynowski \& Simoneit 2009).

Among the various tetrapod lineages that originated/ radiated during the Late Triassic (e.g., anurans, turtles, lepidosaurs, mammals), archosaurs deserve particular interest for their great diversity, morphological disparity and dominance of terrestrial ecosystems during the remainder of the Mesozoic Era (in the form of dinosaurs, pterosaurs and crocodyliforms) and, during the Cenozoic, in the form of crocodylians and birds (including $>10,000$ living species). Although the split between the crocodylian and avian lineages occurred very early within the Triassic (Nesbitt et al. this volume), a great deal of the cladogenetic events that set the grounds for the latter evolution of archosaurs occurred during the Late Triassic (Brusatte et al. this volume; Irmis this volume) including the split of Dinosauria into its main clades (Ornithischia, Sauropodomorpha and Theropoda) and the origin of Crocodyliformes (Pol et al. 2009).

Dinosaurs originated from a grade of small gracile archosaurs generally termed 'basal dinosauromorphs'. Formerly known only from Middle Triassic deposits of Argentina, various recent finds and reanalyses (Dzik 2003; Ezcurra 2006; Ferigolo \& Langer 2007; Irmis et al. 2007; Nesbitt et al. 2007, 2010) have increased both their geographical and chronological record, further enlarged with the recent inclusion of Saltopus elginensis in the group (Benton \& Walker this volume). Some of these basal dinosauromorphs may form an unusual clade of long-armed, beaked forms, the silesaurids (Langer et al. 2010; Nesbitt et al. 2010), with records occurring through most of the Mid-Late Triassic, in Africa, Europe and South and North America.
Following two previous booms of discoveries during the early (Sereno \& Novas 1992; Sereno et al. 1993) and late (Bonaparte et al. 1999; Langer et al. 1999) 1990s, the last few years witnessed a burst of exciting discoveries of early dinosaurs. These have included: an herrerasaurid, Sanjuansaurus gordilloi (Alcober \& Martinez 2010) and two basal sauropodomophs, Panphagia protos (Martinez \& Alcober 2009) and Chromogisaurus novasi (Ezcurra 2010b), from the Ischigualasto Formation of Argentina; Tawa hallae, a new basal theropod, from the Chinle Formation of western USA (Nesbitt et al. 2009); the only well known Triassic ornithischian, Eocursor parvus, from the lower Elliot Formation of South Africa (Butler et al. 2007; Butler 2010); and two new basal sauropodomophs from the Upper Maleri Formation of India (Novas et al. this volume). In addition to a better understanding of the phylogenetic positions of these taxa, reinterpretations of previously known taxa such as Aliwalia rex (Yates 2007), Guaibasaurus candelariensis (Langer et al. this volume), Heterodontosaurus tucki (Butler et al. 2007, 2008; Porro et al. this volume), Staurikosaurus pricei (Bittencourt \& Kellner 2009) and Zupaysaurus rougieri (Ezcurra \& Novas 2007), have also helped to unravel basal dinosaur evolution.

Despite these contributions, various aspects of early dinosaur phylogeny remain controversial. Basal ornithischian phylogeny is particularly problematic, with Eocursor parvus, Lesothosaurus diagnosticus and heterodontosaurids placed in very different positions according to the recent published hypotheses (Sereno 1999; Xu et al. 2006; Butler et al. 2007, 2008, 2010). Among saurischians, Guaibasaurus candelariensis is placed within either the sauropodomorph (Ezcurra 2010b; Novas et al. this volume) or theropod (Langer et al. this volume) lineages, as is also the case for the very fragmentary Agnosphitys cromhallensis (Yates 2007; Ezcurra 2010b). However, the most contentious and longest-lasting issue is the position of herrerasaurids, with recent publications endorsing (Sereno 2007; Nesbitt et al. 2009, 2010) or rejecting (Langer \& Benton 2006; Irmis et al. 2007; Yates 2007; Alcober \& Martinez 2010; Ezcurra 2010b; Novas et al. this volume) their theropod affinities. The putative herrerasaurid Chindesaurus bryansmalli also has an erratic position, and was considered a basal theropod even in phylogenies that excluded coreherrerasaurids from the group (Yates 2007; Novas et al. this volume). Finally, Eoraptor lunensis has also been alternatively nested within (Sereno 2007; Nesbitt et al. 2009; Ezcurra 2010b) or outside (Langer \& Benton 2006; Yates 2007; Alcober \& Martinez 2010) Theropoda.

Sereno (2007) discussed the possible reasons for this discrepancy of opinions. Although there is certainly space for broader taxon and character sampling, and for more precise character state definitions, we believe that this is also a measure of the dynamic nature of the field of research, with numerous studies scrutinising a relatively short segment of evolutionary history. However, among the drawbacks of an ambiguous phylogenetic framework is its limitation as a foundation for ongoing meta-analytical approaches to understanding macroevolution (e.g., Barrett et al. this volume). As so often in palaeontology, we hope that further finds and more comprehensive phylogenetic studies may provide a stronger basis for macroevolutionary work.

The palaeobiology and palaeoecology of Late Triassic terrestrial tetrapods and their ecosystems remain relatively little studied, and represent a promising avenue for future research. For example, there has been considerable interest historically in dietary preferences among Triassic tetrapods (e.g., Crompton \& Attridge 1986; Galton 1986; Barrett 2000; Reisz \& Sues 2000; Small 2002; Barrett et al. this volume), particularly focusing on multiple independent origins of herbivory 
and the possibility that tetrapod faunal turnover was driven by changes in floral palaeocommunities (e.g., Benton 1983). Recent discoveries of apparently omnivorous and/or herbivorous silesaurids and reevaluations of archosaur phylogeny have led to reexaminations of dietary evolution amongst early dinosaurs and closely related taxa, questioning long held assumptions (Nesbitt et al. 2010; Barrett et al. this volume). The continued development of such work, combined with careful functional work focusing on exemplar taxa (e.g., Desojo \& Vizcaíno 2009; Porro 2009) and better understanding of environmental differences between fossil sites, should begin to yield insights into palaeocommunity structure and evolution.

Historically, work on Triassic biogeography has been qualitative in nature, and has focused on the presence or absence of major barriers to faunal exchange on the Pangaean supercontinent and the potential influence of climate-driven latitudinal variations in faunas (e.g., Olsen \& Galton 1984). Quantitative analyses were pioneered by Shubin \& Sues (1991), but have remained relatively scarce, despite the toolkit of possible palaeobiogeographical approaches available. Palaeontologists are now finally beginning to explore these methods in detail: for example, Nesbitt et al. (2009) used likelihood-based methods to assess ancestral areas and dispersal events among early dinosaurs, whereas Ezcurra (2010a) used treereconciliation analysis and a novel approach in which palaeolatitude is mapped onto area cladograms to examine the biogeography of Triassic tetrapods more broadly. Both studies found quantitative evidence for an important role of palaeolatitude in determining Triassic biogeography. These alternative methodological approaches address subtly different questions, and there is as yet no empirical evidence as to which of the multitude of available biogeographical techniques is most likely to give reliable results. Moreover, these studies represent the tip of the iceberg in terms of possible methodologies and datasets, and it is likely that ongoing work, combined with new data and increasingly detailed phylogenies, will yield further new insights.

Macroevolutionary work on Triassic faunas has generally focused on taxonomic diversity, beginning with the pioneering, although often controversial, global studies of Benton (1983, 1994; see also Brusatte et al. this volume), which examined the evidence for Triassic extinction events and their impact on Triassic terrestrial tetrapods. Recent work has stressed that such global analyses should be treated with caution, due to the the problems of stratigraphic correlation and the possibilities of differing regional signals (e.g. Irmis this volume). Although no similar global study of all tetrapods has been carried out since Benton (1994), work has focused on individual clades (e.g., Fröbisch 2008; Barrett et al. 2009, this volume; Abdala \& Ribeiro 2010; Ezcurra 2010b; Brusatte et al. this volume; Irmis this volume; Novas et al. this volume), and has often attempted to incorporate phylogenetic data on missing lineages. Another new approach looks at diversity shifts (increase in lineage diversification) based on phylogenetic hypotheses (Lloyd et al. 2008; Brusatte et al. this volume), finding evidence for increases in diversification rate in early dinosaur evolution. Analyses of disparity (morphological diversity) and rates of character evolution have recently been carried out for Triassic archosaur datasets (Brusatte et al. 2008, this volume; Cisneros \& Ruta 2010), and provide a potentially highly informative counterpart to studies of taxonomic diversity. Methods of ancestral state reconstruction have rarely been applied to Triassic tetrapods, but they have recently been used to investigate topics such as the early evolution of dinosaur body size (Carrano 2006; Irmis this volume).

The elephant in the room for all of these macroevolutionary studies is, however, the effect of uneven spatiotemporal sam- pling on observed patterns. Recent work has suggested that sampling biases may cause severe problems for studies of taxonomic diversification (e.g., Smith \& McGowan 2007; Barrett et al. 2009; Butler et al. 2011); the effects of uneven fossil record sampling on patterns of disparity and character rates remain largely unstudied, although some theoretical work implies that they should be more robust to such biases (e.g. Ciampaglio et al. 2001). Some recent early Mesozoic studies have attempted to correct for geologic biases (e.g., Fröbisch 2008; Lloyd et al. 2008; Barrett et al. 2009; Irmis this volume), but more comprehensive solutions are necessary. Uneven fossil record sampling is, however, not a reason to abandon such macroevolutionary work: increasingly sophisticated approaches aim to identify and ameliorate sampling biases via sampling standardisation (e.g., Alroy 2010) or multiple regression based modelling approaches (e.g., Marx \& Uhen 2010; Benson \& Butler in press). Future advances in the understanding of Triassic diversity patterns will require robust new databases, detailed phylogenetic hypotheses, better stratigraphic correlations and careful consideration of sampling biases.

\section{Acknowledgements}

We thank the organising and program committees of the Bristol SVP meeting for allowing us to hold the symposium that led to this volume, and the Systematics Association for partially funding attendance for two participants. Our thanks also go to all the vertebrate palaeontologists who participated in and attended the symposium. Many thanks are due to the Royal Society of Edinburgh for their help in producing this volume, with particular thanks to Vicki Hammond, who oversaw and organised the entire publication process, and Andrew Smith for his editorial work. Jeffrey Martz provided the illustration which graces the cover of this volume. Additional thanks are due to all colleagues who reviewed the manuscripts presented herein.

\section{References}

Abdala, F. \& Ribeiro, A. M. 2010. Distribution and diversity patterns of Triassic cynodonts (Therapsida, Cynodontia) in Gondwana. Palaeogeography, Palaeoclimatology, Palaeoecology 286, 202-17.

Alcober, O. \& Martinez, R. N. 2010. A new herrerasaurid (Dinosauria, Saurischia) from the Upper Triassic Ischigualasto Formation of northwestern Argentina. ZooKeys 63, 55-81.

Alroy, J. 2010. Geographical, environmental and intrinsic biotic controls on Phanerozoic marine diversification. Palaeontology 53, 1211-35.

Barrett, P. M. 2000. Prosauropods and iguanas: speculation on the diets of extinct reptiles. In Sues, H.-D. (ed.) Evolution of Herbivory in Terrestrial Vertebrates: Perspectives from the Fossil Record, 42-78. Cambridge, UK: Cambridge University Press.

Barrett, P. M., McGowan, A. J. \& Page, V. 2009. Dinosaur diversity and the rock record. Proceedings of the Royal Society B 276, 2667-74.

Benson, R. B. J. \& Butler, R. J. In press. Uncovering the diversification history of marine tetrapods: ecology influences the effect of geological sampling biases. Geological Society, London, Special Publication.

Benton, M. J. 1983. Dinosaur success in the Triassic: a noncompetitive ecological model. Quarterly Review of Biology 58, 29-55.

Benton, M. J. 1994. Late Triassic to Middle Jurassic extinctions among continental tetrapods: testing the pattern. In Fraser, N. C. \& Sues, H.-D. (eds) In the Shadow of the Dinosaurs: Early Mesozoic Tetrapods, 366-97. Cambridge, UK: Cambridge University Press.

Bittencourt, J. S. \& Kellner, A. W. A. 2009. The anatomy and phylogenetic position of the Triassic dinosaur Staurikosaurus pricei Colbert, 1970. Zootaxa 2079, 1-56.

Bonaparte, J. F., Ferigolo, J. \& Ribeiro, A. M. 1999. A new Early Triassic saurischian dinosaur from Rio Grande do Sul State, 
Brazil. In Tomida, Y., Rich, T. H. \& Vickers-Rich, P. (eds) Proceeding of the Second Gondwana Dinosaur Symposium. National Science Museum Monographs 15, 89-109. Tokyo: National Science Museum.

Brusatte, S. L., Benton, M. J., Ruta, M. \& Lloyd, G. T. 2008. Superiority, competition, and opportunism in the evolutionary radiation of dinosaurs. Science 321, 1485-88.

Brusatte, S. L., Nesbitt, S. J., Irmis, R. B., Butler, R. J., Benton, M. J. \& Norell, M. A. 2010. The origin and early radiation of dinosaurs. Earth-Science Reviews 101, 68-100.

Butler, R. J. 2010. The anatomy of the basal ornithischian dinosaur Eocursor parvus from the lower Elliot Formation (Late Triassic) of South Africa. Zoological Journal of the Linnean Society 160, 648-84.

Butler, R. J., Smith, R. M. H. \& Norman, D. B. 2007. A primitive ornithischian dinosaur from the Late Triassic of South Africa and the early evolution and diversification of Ornithischia. Proceedings of the Royal Society B 274, 2041-46.

Butler, R. J., Upchurch, P. \& Norman, D. B. 2008. The phylogeny of the ornithischian dinosaurs. Journal of Systematic Palaeontology 6, $1-40$.

Butler, R. J., Galton, P. M., Porro, L. B., Chiappe, L. M., Henderson, D. M. \& Erickson, G. M. 2010. Lower limits of ornithischian dinosaur body size inferred from a new Upper Jurassic heterodontosaurid from North America. Proceedings of the Royal Society B 277, 375-81.

Butler, R. J., Benson, R. B. J., Carrano, M. T., Mannion, P. D. \& Upchurch, P. 2011. Sea-level, dinosaur diversity, and sampling biases: investigating the 'common cause' hypothesis in the terrestrial realm. Proceedings of the Royal Society B 278, 1165-70.

Carrano, M. T. 2006. Body-size evolution in the Dinosauria. In Carrano, M. T., Gaudin, T. J., Blob, R. W. \& Wible, J. R. (eds) Amniote Paleobiology: Perspectives on the Evolution of Mammals, Birds, and Reptiles, 225-68. Chicago: University of Chicago Press.

Ciampaglio, C. N., Kemp, M. \& McShea, D. W. 2001. Detecting changes in morphospace occupation patterns in the fossil record: characterization and analysis of measures of disparity. Paleobiology 27, 695-715.

Cisneros, J. C. \& Ruta, M. 2010. Morphological diversity and biogeography of procolophonids (Amniota: Parareptilia). Journal of Systematic Palaeontology 8, 607-25.

Cornet, B. 1993. Applications and limitations of palynology in age, climatic, and paleoenvironmental analyzes of Triassic sequences in North America. In Lucas, S. G. \& Morales, M. (eds) The non-marine Triassic. New Mexico Museum of Natural History and Science Bulletin 3, 75-93. Albuquerque: New Mexico Museum of Natural History and Science.

Crompton, A. W. \& Attridge, J. 1986. Masticatory apparatus of the larger herbivores during Late Triassic and Early Jurassic time. In Padian, K. (ed.) The Beginning of the Age of the Dinosaurs, 223-36. Cambridge, UK: Cambridge University Press.

Desojo, J. B. \& Vizcaíno, S. F. 2009. Jaw biomechanics in the South American aetosaur Neoaetosauroides engaeus. Paläontologische Zeitschrift 83, 499-510.

Dunlavey, M. G., Whiteside, J. H. \& Irmis, R. B. 2009. Ecosystem instability during the rise of dinosaurs: evidence from the Late Triassic in New Mexico and Arizona. Geological Society of America Abstracts with Programs 41, 477.

Dzik, J. 2003. A beaked herbivorous archosaur with dinosaur affinities from the early Late Triassic of Poland. Journal of Vertebrate Paleontology 23, 556-74.

Dzik, J., Sulej, T. \& Niedźwiedzki, G. 2008. A dicynodont-theropod association in the latest Triassic of Poland. Acta Palaeontologica Polonica 53, 733-38.

Ezcurra, M. D. 2006. A review of the systematic position of the dinosauriform archosaur Eucoelophysis baldwini from the Upper Triassic of New Mexico, USA. Geodiversitas 28, 649-84.

Ezcurra, M. D. 2010a. Biogeography of Triassic tetrapods: evidence for provincialism and driven sympatric cladogenesis in the early evolution of modern tetrapod lineages. Proceedings of the Royal Society B 277, 2547-52.

Ezcurra, M. D. 2010b. A new early dinosaur (Saurischia: Sauropodomorpha) from the Late Triassic of Argentina: a reassessment of dinosaur origin and phylogeny. Journal of Systematic Palaeontology 8, 371-425.

Ezcurra, M. D. \& Novas, F. E. 2007. Phylogenetic relationships of the Triassic theropod Zupaysaurus rougieri from NW Argentina. Historical Biology 19, 35-72.

Ferigolo, J. \& Langer, M. C. 2007. A Late Triassic dinosauriform from south Brazil and the origin of the ornithischian predentary bone. Historical Biology 19, 23-33.
Fraser, N. C. 2006. Dawn of the Dinosaurs: Life in the Triassic. Bloomington: Indiana University Press.

Fraser, N. C. \& Sues, H.-D. (eds) 1994. In the Shadow of the Dinosaurs: Early Mesozoic Tetrapods. Cambridge, UK: Cambridge University Press.

Fröbisch, J. 2008. Global taxonomic diversity of anomodonts (Tetrapoda, Therapsida) and the terrestrial rock record across the Permian-Triassic boundary. PLoS ONE 3: e3733, 1-14.

Galton, P. M. 1986. Herbivorous adaptations of Late Triassic and Early Jurassic dinosaurs. In Padian, K. (ed.) The Beginning of the Age of the Dinosaurs, 203-21. Cambridge, UK: Cambridge University Press.

Irmis, R. B., Nesbitt, S. J., Padian, K., Smith, N. D., Turner, A. H., Woody, D. \& Downs, A. 2007. A Late Triassic dinosauromorph assemblage from New Mexico and the rise of dinosaurs. Science 317, 358-61.

Irmis, R. B., Martz, J. W., Parker, W. G. \& Nesbitt, S. J. 2010. Re-evaluating the correlation between Late Triassic terrestrial vertebrate biostratigraphy and the GSSP-defined marine stages. Albertiana 38, 40-52.

Irmis, R. B. \& Mundil, R. 2008. New age constraints from the Chinle Formation revise global comparisons of Late Triassic vertebrate assemblages. Journal of Vertebrate Paleontology 28 (suppl. to 3), 95A.

Irmis, R. B. \& Mundil, R. 2010. New U-Pb zircon ages from the Chinle Formation (western US) revise understanding of Late Triassic terrestrial vertebrate evolution. Geological Society of America Abstracts with Programs 42, 393.

Irmis, R. B. \& Whiteside, J. H. 2010. Newly integrated approaches to studying Late Triassic terrestrial ecosystems. Palaios 25, 689-91.

Kent, D. V. \& Olsen, P. E. 1999. Astronomically tuned geomagnetic polarity timescale for the Late Triassic. Journal of Geophysical Research B 104, 12831-41.

Langer, M. C. 2005. Studies on continental Late Triassic tetrapod biochronology. II. The Ischigualastian and a Carnian global correlation. Journal of South American Earth Sciences 19, 219-39.

Langer, M. C., Abdala, F., Richter, M. \& Benton, M. J. 1999. A sauropodomorph dinosaur from the Upper Triassic (Carnian) of southern Brazil. Comptes Rendus de l'Académie des Sciences, Sciences de la Terre et des Planètes 329, 511-17.

Langer, M. C., Ezcurra, M. D., Bittencourt, J. S. \& Novas, F. E. 2010. The origin and early evolution of dinosaurs. Biological Reviews 85, 55-110.

Langer, M. C. \& Benton, M. J. 2006. Early dinosaurs: a phylogenetic study. Journal of Systematic Palaeontology 4, 309-58.

Litwin, R. J., Traverse, A. \& Ash, S. R. 1991. Preliminary palynological zonation of the Chinle Formation, southwestern U.S.A., and its correlation to the Newark Supergroup (eastern USA). Review of Palaeobotany and Palynology 68, 269-87.

Lloyd, G. T., Davis, K. E., Pisani, D., Tarver, J. E., Ruta, M., Sakamoto, M., Hone, D. W. E., Jennings, R. \& Benton, M. J. 2008. Dinosaurs and the Cretaceous terrestrial revolution. Proceedings of the Royal Society B 275, 2483-90.

Lucas, S. G. 1998. Global Triassic tetrapod biostratigraphy and biochronology. Palaeogeography, Palaeoclimatology, Palaeoecology 143, 347-84.

Lucas, S. G. 2010. The Triassic timescale based on nonmarine tetrapod biostratigraphy and biochronology. Geological Society, London, Special Publication 334, 447-500.

Martinez, R. N. \& Alcober, O. A. 2009. A basal sauropodomorph (Dinosauria: Saurischia) from the Ischigualasto Formation (Triassic, Carnian) and the early evolution of Sauropodomorpha. PLOS ONE 4: e4397, 1-12.

Marx, F. G. \& Uhen, M. D. 2010. Climate, critters, and cetaceans: Cenozoic drivers of the evolution of modern whales. Science 327, 993-96.

Marynowski, L. \& Simoneit, B. R. T. 2009. Widespread Upper Triassic to Lower Jurassic wildfire records from Poland: evidence from charcoal and pyrolytic polycyclic aromatic hydrocarbons. Palaios 24, 785-98.

Mundil, R., Pálfy, J., Renne, P. R. \& Brack, P. 2010. The Triassic time scale: new constraints and a review of geochronological data. Geological Society, London, Special Publication 334, 41-60.

Muttoni, G., Kent, D. V., Olsen, P. E., Di Stefano, P., Lowrie, W., Bernasconi, S. M. \& Hernandez, F. M. 2004. Tethyan magnetostratigraphy from Pizzo Mondello (Sicily) and correlation to the Late Triassic Newark astrochronological polarity time scale. Geological Society of America Bulletin 116, 1043-58.

Nesbitt, S. J., Irmis, R. B., \& Parker, W. G. 2007. A critical reevaluation of the Late Triassic dinosaur taxa of North America. Journal of Systematic Palaeontology 5, 209-43. 
Nesbitt, S. J., Smith, N. D., Irmis, R. B., Turner, A. H., Downs, A. \& Norell, M. A. 2009. A complete skeleton of a Late Triassic saurischian and the early evolution of dinosaurs. Science 326, 1530-33.

Nesbitt, S. J., Sidor, C. A., Irmis, R. B., Angielczyk, K. D., Smith, R. M. H. \& Tsuji, L. A. 2010. Ecologically distinct dinosaurian sister group shows early diversification of Ornithodira. Nature 464, 95-98.

Olsen, P. E. \& Galton, P. M. 1984. A review of the reptile and amphibian assemblages from the Stormberg Group of southern Africa with special emphasis on the footprints and the age of the Stormberg. Palaeontologia Africana 25, 87-110.

Padian, K. (ed.) 1986. The Beginning of the Age of Dinosaurs: Faunal Changes Across the Triassic-Jurassic Boundary. Cambridge, UK: Cambridge University Press.

Pol, D., Turner, A. H. \& Norell, M. A. 2009. Morphology of the Late Cretaceous crocodylomorph Shamosuchus djadochtaensis and a discussion of neosuchian phylogeny as related to the origin of Eusuchia. Bulletin of the American Museum of Natural History 324, 1-103.

Porro, L. B. 2009. Cranial biomechanics in the early dinosaur Heterodontosaurus. Unpublished $\mathrm{PhD}$ Thesis. University of Cambridge.

Ramezani, J., Bowring, S. A., Fastovsky, D. E. \& Hoke, G. D. 2009. U-Pb ID-TIMS geochronology of the Late Triassic Chinle Formation, Petrified Forest National Park, Arizona. Geological Society of America Abstracts with Programs 41, 421.

Rayfield, E. J., Barrett, P. M., McDonnell, R. A. \& Willis, K. J. 2005. A Geographical Information System (GIS) study of Triassic vertebrate biochronology. Geological Magazine 142, 327-54.

Rayfield, E. J., Barrett, P. M. \& Milner, A. R. 2009. Utility and validity of Middle and Late Triassic 'land vertebrate faunachrons'. Journal of Vertebrate Paleontology 29, 80-87.

Reisz, R. R. \& Sues, H.-D. 2000. Herbivory in late Paleozoic and Triassic terrestrial vertebrates. In Sues, H.-D. (ed.) The Evolution of Herbivory in Terrestrial Vertebrates: perspectives from the fossil record, 9-41. Cambridge, UK: Cambridge University Press.

Rogers, R. R., Swisher, C. C., III, Sereno, P. C., Monetta, A. M., Forster, C. A. \& Martínez, R. N. 1993. The Ischigualasto tetrapod assemblage (Late Triassic, Argentina) and ${ }^{40} \mathrm{Ar} /{ }^{39} \mathrm{Ar}$ dating of dinosaur origins. Science 260, 794-97.

Schultz, C. L. 2005. Biostratigraphy of the non-marine Triassic: is a global correlation based on tetrapod faunas possible? In Koutsoukos, E. A. M. (ed.) Applied Stratigraphy, 123-45. Dordrecht: Springer.

Sereno, P. C. 1999. The evolution of dinosaurs. Science 284, 2137-47.

Sereno, P. C. 2007. The phylogenetic relationships of early dinosaurs: a comparative report. Historical Biology 19, 145-55.

Sereno, P. C., Forster C. A., Rogers, R. R. \& Monetta, A. A. M. 1993. Primitive dinosaur skeleton from Argentina and the early evolution of Dinosauria. Nature 361, 64-66.

Sereno, P. C. \& Novas, F. E. 1992. The complete skull and skeleton of an early dinosaur. Science 258, 1137-40.

Shubin, N. H. \& Sues, H.-D. 1991. Biogeography of early Mesozoic continental tetrapods: patterns and implications. Paleobiology 17, 214-30.

Small, B. J. 2002. Cranial anatomy of Desmatosuchus haplocerus (Reptilia: Archosauria: Stagonolepididae). Zoological Journal of the Linnean Society 136, 97-111.

Smith, A. B. \& McGowan, A. J. 2007. The shape of the marine palaeodiversity curve: how much can be predicted from the sedimentary rock record of western Europe? Palaeontology 50, 765-74.

Sues, H.-D. \& Fraser, N. C. 2010. Triassic life on land: the great transition. New York: Columbia University Press.

Whiteside, J. H., Olsen, P. E., Eglinton, T., Brookfield, M. E. \& Sambrotto, R. N. 2010. Compound-specific carbon isotopes from Earth's largest flood basalt province directly link eruptions to the end-Triassic mass extinction. Proceedings of the National Academy of Sciences 107, 6721-25.

Xu, X., Forster, C. A., Clark, J. M. \& Mo, J. 2006. A basal ceratopsian with transitional features from the Late Jurassic of northwestern China. Proceedings of the Royal Society B 273, 2135-40.

Yates, A. M. 2007. Solving a dinosaurian puzzle: the identity of Aliwalia rex Galton. Historical Biology 19, 93-123.

MS received 21 December 2010. Accepted for publication 11 January 2011. 